\title{
ANALYSIS OF TOXIC EFFECT OF INDUSTRIAL EFFLUENT ON LABEO ROHITA IN THE RIVER RAM GANGA AT MORADABAD
}

\author{
Bhupander Kumar ${ }^{1}$, Vikas Gupta ${ }^{2}$ \\ ${ }^{1}$ Research Scholar Shri Venkateshwara University, Gajurala J.P. Nagar (U.P) \\ ${ }^{2}$ IFTM University, Moradabad-244001, (U.P)
}

\begin{abstract}
The industrial waste effluents generally contain heavy metals like $\mathrm{Pb}, \mathrm{Cr}$ and $\mathrm{Cu}$ etc., dumped into rivers. In present study, the toxicity of industrial effluent was investigated using fish "Labeo Rohita" and found that fish was unable to survive even in 15\% concentration of the effluent. An interesting feature of the study was that when the $\mathrm{pH}$ of the effluent decreased the toxicity of the effluent increased several times. It also found by the study that among three metals $\mathrm{Pb}, \mathrm{Cr}$ and $\mathrm{Cu}$, Chromium is more toxic than other two metals. The results also shows that the Cr toxicity in enhanced at lower $\mathrm{pH}$ - 5.5. This result is in agreement with the already established toxicity which reported that high $\mathrm{Cr}$ accumulation occurred at lower $\mathrm{pH}-6.5$ that of high $\mathrm{pH}-7.8$. It also established by the present investigation that as the $\mathrm{pH}$ decreases, the toxicity of the metal increases.
\end{abstract}

Keywords: Industrial Effluents, Heavy Metals, Labeo Rohita Fish, Aquatic Life. ****

\section{INTRODUCTION}

Water is abundantly available on the earth, three fourth to earth's surface is covered by water. Water is essential to all forms of life and makes up 50-97\% of the weight of all plats and animals [1]. In urban areas, the careless disposal of industrial effluents and other wastes in rivers \& lacks may contribute greatly to the poor quality of river water [2-5]. Most of the rivers in the urban areas of the developing countries are the ends of effluents discharged from the industries. Asian countries experiencing rapid industrial growth during last few decade and this is making environmental conservation a difficult task [6]

Moradabad is a B-class city of Uttar Pradesh, having urban population more than 10 lakh. The city is full of brass, steel \& glass cottage industries. A paper industry, some electroplating plants \& other small-scale industries situated in Moradabad.. All these industries are in unorganized sector and thus have unplanned growth leaving to high degree of air, water and soil pollution. The most of the industries are dumping their effluents in two major rivers of the city- Ramganga River \& Gagan River. The effluent containing heavy metals is largely the waste by product of industrial process. MATERIALS \& METHODS

The samples collected at two different sites.

Site-1: Untreated $\mathrm{Cu}, \mathrm{Pb}, \& \mathrm{Cr}$ effluents were colleted from the small scale industry situated near the bank of Ram Ganga river which continuously discharging effluents into the river. The samples of effluents collected before mixing in the river.

Site- 2: Effluents sample carrying mixed discharge of industries \& nearby locality after mixing with river water were collected at site II that is almost 1 kilometer far from the site- 1 .

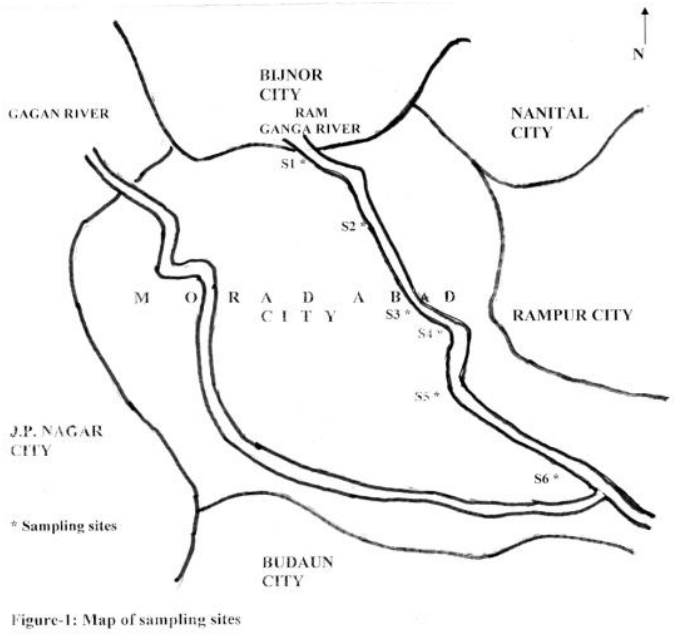

Fig.1: Map of sampling sit

All the samples collected following standard procedure of sampling [8]. The toxicity test were conducted using "Labeo Rohita" (Hamilton) was acclimatized to the laboratory conditions for two weeks using diluents water prepared in the laboratory [9]. The fishes fed daily with a commercial food at a rate of $3 \%$ body wt. per day. The D.O. of the diluents water kept between 4.0-5.0 mg/lit [10]. The $\mathrm{pH}$, hardness, alkalinity, Conductivity, COD of the diluents water kept almost same as that of fresh river water.

Different solution of effluents were prepared with diluents water $(100 \%, 50 \%, 25 \%, 10 \%)$ and were taken separately in 5 lit capacity glass Jars and acclimatized fish (6 each) were put in all beakers. Before conducting the tests, the fish kept hungry for $24 \mathrm{hrs}$.

The acclimatized fish also kept in diluents water as control. The test conducted continuously for $96 \mathrm{hrs}$. The metal $(\mathrm{Pb}$, 
$\mathrm{Cu}$, and $\mathrm{Cr}$ ) concentration in effluents analyzed on AAS (Atomic absorption spectrophotometer) and the $\mathrm{pH}$ measured directly either in the effluent or in the river using a pH-meter. Table-1 shows a variation in both concentration and $\mathrm{pH}$ in sample collected from site- 1 and site- 2 .

Table 1: Site wise estimation of $\mathrm{Cu}, \mathrm{Pb} \& \mathrm{Cr}$ metals in industrial effluents mixing in Ram Ganga river ( $\mathrm{mg} / \mathrm{lit}$ )

\begin{tabular}{|l|l|l|l|}
\hline S.No. & Metal & $\begin{array}{l}\text { Site-1 } \\
\text { (At the } \\
\text { dischargi } \\
\text { ng } \\
\text { source) }\end{array}$ & $\begin{array}{l}\text { Site-2 } \\
\text { (After } \\
\text { mixing } \\
\text { in } \\
\text { river) }\end{array}$ \\
\hline 1. & Copper $(\mathrm{Cu})$ & 44.0 & 0.578 \\
\hline 2. & Lead $(\mathrm{Pb})$ & 31.0 & 0.582 \\
\hline 3. & Chromium $(\mathrm{Cr})$ & 29.0 & 0.429 \\
\hline
\end{tabular}

\section{RESULTS \& DISCUSSION}

The findings of all the experiments summarized in Table 2. In case of $\mathrm{Cr}$, it is clear from the table that all the six fishes died immediately after their transfer to the effluents. Even in case of $10 \%$ concentration of effluents sample, no fish survived after $24 \mathrm{hrs}$. It clearly indicates the toxicity of $\mathrm{Cr}$ metal. In the present investigation, it observed that survival is $70 \%$ after $24 \mathrm{hrs}, 50 \%$ after $48 \mathrm{hrs}$ and no survival after $96 \mathrm{hrs}$ in undiluted sample containing $\mathrm{Pb}$ metal ion and it established that $\mathrm{Pb}$ has lesser toxicity than $\mathrm{Cr}$.

$\mathrm{Pb}, \mathrm{Cr} \& \mathrm{Cu}$ when mixed in 1:1:1 ratio shows a synergetic toxic effect. There was no survival immediately after transfer of fish at $100 \%$ concentration and $50 \%$ survival at $50 \%$ concentration. This river water has very small concentration of $\mathrm{Pb}, \mathrm{Cr} \& \mathrm{Cu}$ but still showing severe toxic effect as only $2 \%$ survival observed after 96 hrs.

Table 2: Survival rates of fishes at various concentrations at different $\mathrm{pH}$

\begin{tabular}{|c|c|c|c|c|c|c|c|c|}
\hline \multirow[t]{2}{*}{ S.No. } & \multirow[t]{2}{*}{ Solution } & \multirow{2}{*}{$\begin{array}{l}\text { Concentration } \\
\%\end{array}$} & \multirow[t]{2}{*}{$\mathbf{p H}$} & \multicolumn{5}{|c|}{ No. of fish survived at different time interval } \\
\hline & & & & $\mathbf{0}$ & 12 & 24 & 48 & 96 \\
\hline 1. & Diluents water & 100 & 8.5 & $* *$ & $* *$ & $* *$ & $* *$ & $* *$ \\
\hline \multirow[t]{5}{*}{2.} & \multirow{5}{*}{$\begin{array}{l}\text { Copper effluent } \\
\text { (42 mg/lit) }\end{array}$} & 100 & \multirow{5}{*}{8.5} & $* *$ & $* *$ & $* *$ & $* *$ & 5 \\
\hline & & 50 & & $* *$ & $* *$ & $* *$ & $* *$ & 5 \\
\hline & & 25 & & $* *$ & $* *$ & *** & $* *$ & $* *$ \\
\hline & & 10 & & $* *$ & $* *$ & $* *$ & $* *$ & $* *$ \\
\hline & & 1 & & $* *$ & $* *$ & $* *$ & $* *$ & $* *$ \\
\hline \multirow[t]{5}{*}{3.} & \multirow{5}{*}{$\begin{array}{l}\text { Lead effluent } \\
\text { (12 mg/lit) }\end{array}$} & 100 & \multirow{5}{*}{8.5} & $* *$ & $* *$ & 4 & 3 & None \\
\hline & & 50 & & $* *$ & $* *$ & 5 & 5 & 3 \\
\hline & & 25 & & $* *$ & $* *$ & $* *$ & 4 & 4 \\
\hline & & 10 & & $* *$ & $* *$ & $* *$ & $* *$ & 5 \\
\hline & & 1 & & $* *$ & $* *$ & $* *$ & $* *$ & 5 \\
\hline \multirow[t]{5}{*}{4.} & \multirow{5}{*}{$\begin{array}{l}\text { Chromium } \\
\text { effluent } \\
\text { (19 mg/lit) }\end{array}$} & 100 & \multirow{5}{*}{8.5} & None & & & & \\
\hline & & 50 & & 5 & None & & & \\
\hline & & 25 & & $* *$ & 5 & None & & \\
\hline & & 10 & & $* *$ & $* *$ & None & & \\
\hline & & 1 & & $* *$ & $* *$ & 4 & 3 & 2 \\
\hline \multirow[t]{5}{*}{5.} & \multirow{5}{*}{$\begin{array}{l}\text { Copper, Lead \& } \\
\text { Chromium } \\
\text { effluent } \\
(1: 1: 1)\end{array}$} & 100 & \multirow{5}{*}{8.5} & None & & & & \\
\hline & & 50 & & 3 & None & & & \\
\hline & & 25 & & $* *$ & 4 & 2 & None & \\
\hline & & 10 & & $* *$ & $* *$ & 4 & None & \\
\hline & & 1 & & $* *$ & $* *$ & $* *$ & 5 & 5 \\
\hline \multirow[t]{5}{*}{6.} & \multirow{5}{*}{$\begin{array}{l}\text { Copper effluent } \\
(0.478 \mathrm{mg} / \mathrm{lit})\end{array}$} & 100 & \multirow{5}{*}{5.5} & $* *$ & $* *$ & $* *$ & 5 & 4 \\
\hline & & 50 & & $* *$ & $* *$ & $* *$ & $* *$ & 5 \\
\hline & & 25 & & $* *$ & $* *$ & $* *$ & $* *$ & $* *$ \\
\hline & & 10 & & $* *$ & $* *$ & $* *$ & $* *$ & $* *$ \\
\hline & & 1 & & $* *$ & $* *$ & $* *$ & $* *$ & $* *$ \\
\hline \multirow[t]{5}{*}{7.} & \multirow{5}{*}{$\begin{array}{l}\text { Lead effluent } \\
(0.122 \mathrm{mg} / \text { lit })\end{array}$} & 100 & \multirow{5}{*}{5.5} & $* *$ & 4 & 4 & 3 & None \\
\hline & & 50 & & $* *$ & $* *$ & 5 & 4 & 2 \\
\hline & & 25 & & $* *$ & $* *$ & 4 & 4 & 3 \\
\hline & & 10 & & $* *$ & $* *$ & $* *$ & 5 & 5 \\
\hline & & 1 & & $* *$ & $* *$ & $* *$ & $* *$ & 5 \\
\hline \multirow[t]{5}{*}{8.} & \multirow{5}{*}{$\begin{array}{l}\text { Chromium } \\
\text { effluent } \\
(0.329 \mathrm{mg} / \text { lit })\end{array}$} & 100 & \multirow{5}{*}{5.5} & None & & & & \\
\hline & & 50 & & None & & & & \\
\hline & & 25 & & 4 & 2 & None & & \\
\hline & & 10 & & $* *$ & 4 & None & & \\
\hline & & 1 & & $* *$ & 5 & 3 & 2 & 2 \\
\hline
\end{tabular}




\begin{tabular}{|c|c|c|c|c|c|c|c|c|}
\hline \multirow[t]{5}{*}{9.} & \multirow{5}{*}{$\begin{array}{l}\text { Copper, Lead \& } \\
\text { Chromium } \\
\text { effluent } \\
(1: 1: 1)\end{array}$} & 100 & \multirow{5}{*}{5.5} & None & & & & \\
\hline & & 50 & & None & & & & \\
\hline & & 25 & & $* *$ & 3 & 2 & None & \\
\hline & & 10 & & $* *$ & 4 & 2 & None & \\
\hline & & 1 & & $* *$ & 4 & 4 & 3 & 2 \\
\hline 10. & $\begin{array}{ll}\text { River } & \text { water } \\
\text { containing } & \\
\text { effluent } & \end{array}$ & 100 & 5.5 & $* *$ & $* *$ & 5 & 3 & 1 \\
\hline
\end{tabular}

**All survived

\section{CONCLUSION}

It is evident from the present investigation that among three metals $\mathrm{Cr}$ is more toxic and but when all the three metal effluents mixed in 1:1:1 ratio the toxicity of other two metals $(\mathrm{Pb} \& \mathrm{Cu})$ increased several times (Table-2). As all the above metals are present in industrial waste and continuously accumulated in river water, pollute the water severely and have toxic effect an aquatic life.

The only solution of the problem is that Governments must do some honest and concrete efforts to stop this exercise of mixing untreated industrial effluents in rivers, and these industries should develop better R\&D activities so that to adopt some different processes to minimize the waste production and ensure not to mix these effluents in the rivers

\section{REFERENCES}

[1] R. A. Bucholz, The greening business, $2^{\text {nd }}$ Ed. Prentice-Hall, London, U. K., 1998.

[2] A. C. Chindah, A. S. Braide and O. C. Sibeudu, Ajeam-Ragee, 2004, 9, 1.

[3] V. Emongor, E. Kealotswe, I. Koorapetse, S. Sankwasa and S. Keikanetswe, J. Appl. Sci., 2005, $5,147$.

[4] A. A. L. Furtado, R. T. Albuquerque, S. G. F. Leite and R.P. Pecanha, Brazilian Journal of Chemical Engineering, 1998, 15, 1.

[5] C. N. C. Ugochukwu, Ajeam-Ragee, 2004, 8, 2730 .

[6] W. K. Kadongola, M.Sc. Thesis, University of Botswana, Botswana, 1997.

[7] J. R. Prajapati, and B. R., Rao, Pollution Research, 2004, 23 (1), 165

[8] APHA, AWWA, WPCF, Standard methods for examination of water and wastewater, $\left(19^{\text {th }} \mathrm{Ed}\right.$.), Washington D.C., 1995.

[9] F. R. Copperdahl, Guidelines for performing static aquatic toxicity bioassay in municipal and industrial waste waters report on California state water Resources Control Board, 1976.

[10] Indian Standards, Bureau of Indian Standard (BIS), New Delhi, pp. 9, 1987. 